\title{
A review of carbonates as hydrocarbon source rocks: basic geochemistry and oil-gas generation
}

\author{
Liu-Wen $\mathrm{Xia}^{1} \cdot$ Jian $\mathrm{Cao}^{1} \cdot$ Ming Wang $^{2} \cdot$ Ju-Lei Mi ${ }^{2} \cdot$ Ting-Ting Wang $^{1}$
}

Received: 15 April 2018 / Published online: 26 July 2019

(c) The Author(s) 2019

\begin{abstract}
Carbonates have been known to act as hydrocarbon source rocks, but their basic geochemical and associated hydrocarbon generation characteristics remain not well understood as they occur with argillaceous source rocks in most cases, and the hydrocarbon generation from each rock type is difficult to distinguish, forming one of puzzling issues within the field of petroleum geology and geochemistry. To improve the understanding of this critical issue, this paper reviews recent advances in this field and provides a summary of key areas that can be studied in future. Results show that carbonate source rocks are generally associated with high-salinity environments with low amounts of terrestrial inputs and low dissolved oxygen contents. Petrographically, these source rocks are dark gray or black, fine-grained, stratified, and contain bacterial and algal bioprecursors along with some other impurities. They generally have low organic matter contents, although these can vary significantly in different cases (e.g., the total organic carbon contents of marine and lacustrine carbonate source rocks in China are generally $0.1 \%-1.0 \%$ and $0.4 \%-4.0 \%$, respectively). These rocks contain type I and type II kerogen, meaning there is a lack of vitrinites. This means that assessment of the maturity of the organic matter in these sediments needs to use non-traditional techniques rather than vitrinite reflectance. In terms of molecular geochemistry, carbonate source rocks have typical characteristics indicative of generally reducing and saline environments and lower organism-dominated bioprecursors of organic matter, e.g., high contents of sulfur compounds, low $\mathrm{Pr} / \mathrm{Ph}$ ratios, and dominance of $n$-alkanes. Most of the carbonate source rocks are typically dominated by D-type organic facies in an oxidized shallow water mass, although high-quality source rocks generally contain A- and B-type organic facies in saline lacustrine and marine-reducing environments, respectively. The hydrocarbon generation model for the carbonate source rocks can involve early, middle, and late stages, with a diversity of hydrocarbons within these rocks, which can be aggregated, adsorbed, enclosed within minerals, or present as inclusions. This in turn implies that the large-scale hydrocarbon expulsion from these rocks is reliant on brittle deformation caused by external forces. Finally, a number of aspects of these source rocks remain unclear and need further study, including the effectiveness of carbonates as hydrocarbon source rocks, bioprecursors, and hydrocarbon generation models of carbonate source rock, and the differences between marine and lacustrine carbonate source rocks.
\end{abstract}

Keywords Saline lacustrine source rocks $\cdot$ Carbonates $\cdot$ Organic facies $\cdot$ Hydrocarbon generation

\section{Introduction}

Edited by Jie Hao

Jian Cao

jcao@nju.edu.cn

1 MOE Key Laboratory of Surficial Geochemistry, School of Earth Sciences and Engineering, Nanjing University, Nanjing 210023, Jiangsu, China

2 Research Institute of Experiment and Testing, PetroChina Xinjiang Oilfield Company, Karamay 834000, Xinjiang, China

Carbonate rocks are sedimentary rocks dominated by carbonate minerals and include two main categories: limestones and dolomites (Ham and Pray 1962; Leighton and Pendexter 1962; Zhao et al. 2016). In classical petroleum geology and geochemistry, these rocks typically form hydrocarbon reservoirs, while some organic-rich carbonate rocks formed in low-energy environments can also act as hydrocarbon source rocks (Tissot and Welte 1984; Katz et al. 2000; Xie et al. 2016), and thus, much more research 
has focused on the reservoir characteristics of these rocks rather than their source rock characteristics in general.

However, more and more cases have indicated that carbonate source rocks are not only widely distributed spatially but also span a significant part of geological history from the Proterozoic to the Cenozoic, and 30\%-40\% of the world's oil and gas reservoirs might have contributions from such rocks (Palacas et al. 1983; Fu and Jia 1984; Jones 1984; Cordell et al. 1992; Daher et al. 2014; Xie et al. 2016). This implies the global importance of carbonate source rocks and has increased research and exploration interests in these units. The previous studies can be divided into two main areas. First, the evaluation criteria for carbonate source rocks, especially the lower limit of total organic carbon (TOC) content, have caused extensive discussion. Hunt (1967) proposed a lower threshold criterion for carbonate source rocks at a TOC of $0.3 \%$, compared with argillaceous source rocks. Later, Jones (1984) and Bissada (1982) argued for a higher threshold criterion at TOC of $1.0 \%$. Then, Chinese scholars further put forward more systematic evaluation criteria for carbonate source rocks, including the abundance, type and maturity of organic matter (Qin et al. 2004; Cheng 2007). Second, characteristics of petroleum produced by carbonate source rocks were discussed. Many scholars have noticed that oil generated from carbonate source rocks usually has relatively lower API gravity than that generated from argillaceous source rocks and could also be relatively light with relatively high API gravity in some cases (Hughes 1984; Edman and Pitman 2010; Al-Khafaji et al. 2017). For example, the average API gravity of oil derived from carbonate source rocks of the Upper Cretaceous Eagle Ford Group, west Texas, USA, is $30^{\circ}$ API (Edman and Pitman 2010) and API gravity of oil sourced from Late Jurassic to Early Cretaceous carbonate source rocks in the Mesopotamian Basin, South Iraq, ranges from $19^{\circ}$ API to $27^{\circ}$ API (Al-Khafaji et al. 2017). Wang et al. (2010) studied the features of organic geochemistry of sulfur-rich petroleum derived from lacustrine carbonate source rocks in the Bohai Bay Basin, East China. Yurchenko et al. (2018) compared the composition of petroleum from carbonate and argillaceous source rocks in the Triassic Shublik Formation, Alaska North Slope, U.S.A. In addition to oil, there are also some studies on natural gas but resulting in great debates. For example, for the middle Ordovician Majiagou Formation, natural gas under evaporites in the Ordos Basin, central China, Yang et al. (2009) argued that the source of this gas accumulation was marine carbonates of the Majiagou Formation based on carbon isotopes of methane. However, Yang et al. (2014) proposed that the gas is mainly sourced from Carboniferous-Permian coal-bearing strata, according to the fact that TOC of
Ordovician marine carbonates is too low to generate large amount of hydrocarbons.

Nevertheless, the study of carbonate source rocks remains controversial and not well known in terms of basic characteristics and genesis because they commonly occur with argillaceous source rocks and to strictly differentiate them is not easy. For example, the differences between marine and lacustrine carbonate source rocks, the lithological characteristics of these units, the effectiveness of hydrocarbon generation, and their hydrocarbon generation models and mechanisms are not well understood. As a consequence, this forms one of the critical issues in the field of petroleum geology and geochemistry.

To improve the understanding of this critical issue, we provide here an overview of the research into these hydrocarbon source rocks based on representative global examples, including the basic geology, geochemistry, and hydrocarbon generation characteristics, and finally fields for future research.

\section{Geology and geochemistry of carbonate source rock}

\subsection{Representative examples of carbonates as hydrocarbon source rocks}

Organic-rich, fine-grained carbonate source rocks are widely distributed and may have contributed $30 \%-40 \%$ of the world's oil and gas that has been identified in reservoirs to date (Jones 1984; Fig. 1, Table 1). The majority of these source rocks formed during the Mesozoic or Cenozoic with the notable exception of Paleozoic-dominated Chinese marine carbonate source rocks (Table 1).

Carbonate source rocks are subdivided into marine and continental end members. Taking China as an example, marine carbonate source rocks were developed in the Sichuan, Tarim, and Ordos basins, which are old, have been deeply buried and contain relatively low amounts of organic matter due to high thermal evolution (Wang et al. 1995; Zhao et al. 2005; Fang et al. 2017). In contrast, the Paleogene Bohai Bay Basin and the western Qaidam Basin are associated with lacustrine carbonate source rocks (Wang et al. 2010) that are similar to those outside of China.

\subsection{Basic geology of carbonate source rock: sedimentary environment and petrography}

It has been commonly accepted that the sedimentary environment of carbonate rock is mostly dry and evaporative, the salinity of the corresponding water mass is high, and the abundance of organic matter is low (Tissot and Welte 1984). Oehler (1984) suggested that carbonate source rocks 


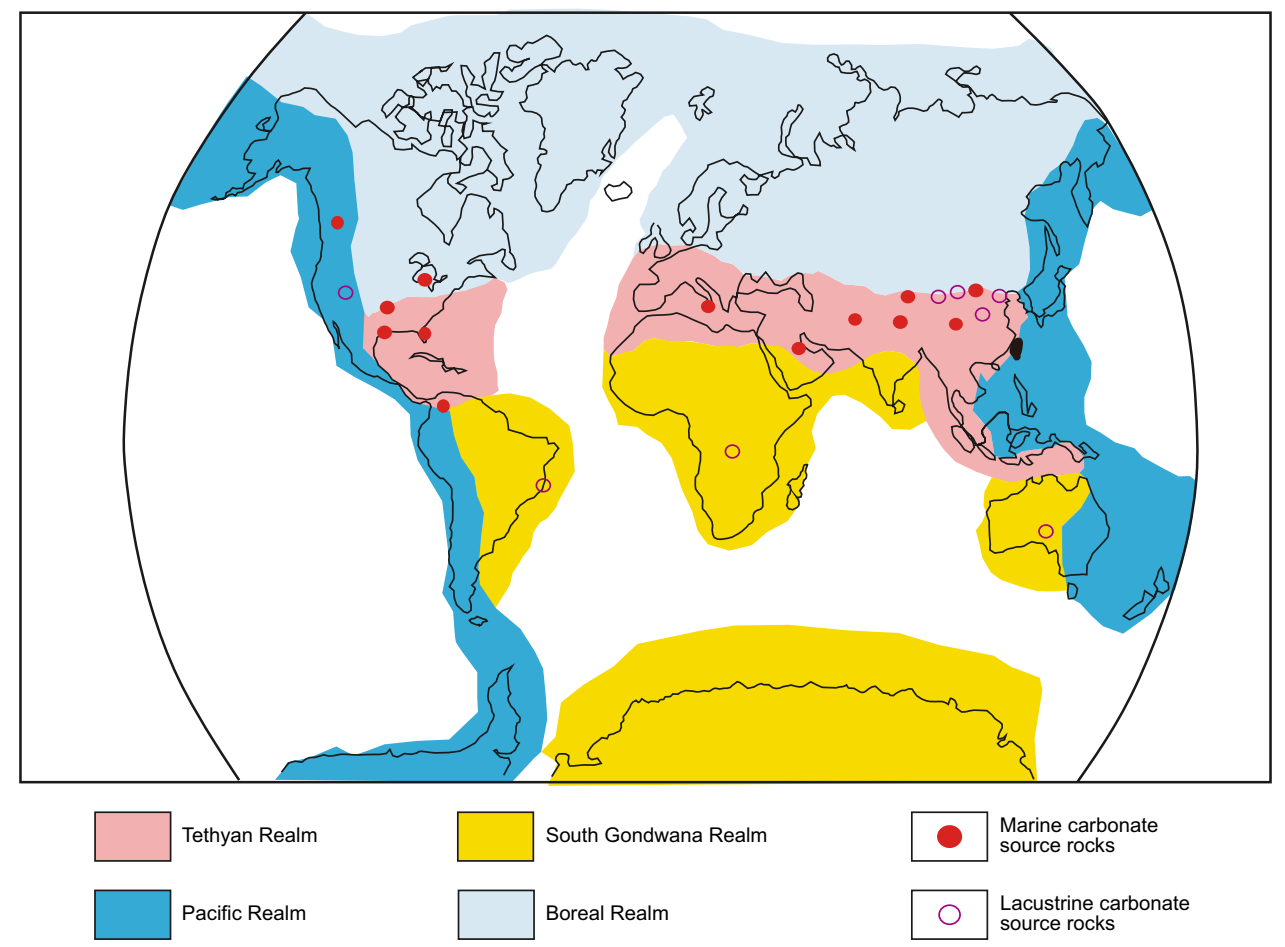

Fig. 1 Global distribution of petroliferous basins that might be associated with carbonate source rocks. Data from Palacas et al. (1983), Stank et al. (1992), Edman and Pitman 2010, Wang et al. (2013), Tian et al. (2014), and Liu et al. (2017)

are generally formed in depositional environments with the following four main characteristics: (1) high salinity and low dissolved oxygen conditions; (2) location in a hydrostatic bottom environment caused by terrain obstacles or stratification of the overlying water mass; (3) high abundances of algae and bacteria as bioprecursors; and (4) relatively low abundances of terrestrial clasts and organic matter. The four types of sedimentary environment that meet these conditions are summarized in Table 2 (Oehler 1984; Zumberge 1984).

In terms of lithology, the majority of the carbonate source rocks that formed in these sedimentary environments are argillaceous limestones and micrites (Huang and Lv 2011). Cordell et al. (1992) summarized the general lithologic characteristics of these source rocks as follows. (1) Generally dark gray or black, suggesting higher organic carbon contents than other associated rocks. (2) Finegrained or microcrystalline, bedded or micro-bedded, with TOC that increases with decreasing particle size (Gehman 1962; Veber and Gorskaya 1965). This may reflect the fact that fine-grained or microcrystalline sediments favor the accumulation of organic material during sedimentation as well as the preservation of this material during diagenesis, while their bedded or micro-bedded structures usually reflect an absence of bioturbation as a result of deposition in an anoxic environment. (3) Numerous algal and bacterial components are present. The bacteria and algae are thought to generate sapropelic kerogen and be the main source of hydrocarbons in these environments associated with evaporite sequences (Kirkland and Evans 1981). (4) Contain varying amounts of clays or other impurities (e.g., fine-grained quartz). In particular, they may contain montmorillonite and illite, both of which tend to absorb organic matter, leading to these impure units containing higher amounts of organic matter than purer carbonates (Hunt and McNichol 1984).

Here, we examine the samples with high carbonate contents from the lower Permian Fengcheng Formation in the Mahu sag of the northwestern Junggar Basin (NW China) as a case study, because few such data of strictly carbonate source rocks are available to the best of our knowledge. This formation is lithologically complex and contains dark gray and algal-residue-rich dolomites, muddy dolomites, tuffaceous dolomites, and dolomitic mudstones (Fig. 2; Cao et al. 2015; Liu et al. 2016; Ren et al. 2017). These dolomites are fine-grained (Fig. 2a) and have carbonate layers that are interbedded with clay layers (Fig. 2b), yielding a stratified structure and indicating that most of these carbonates have high clay contents. They also contain numerous microspores that strongly fluoresce (Fig. 2c), and the fine-grained dolomites also contain red coral algae (Fig. 2d-f). Figure $2 \mathrm{~g}$ shows a benthic macroalgal leaf with an edge that strongly fluoresces. 
Table 1 Representative examples of carbonates as source rocks within and outside China

\begin{tabular}{|c|c|c|c|c|}
\hline $\begin{array}{l}\text { Sedimentary } \\
\text { environment }\end{array}$ & $\begin{array}{l}\text { Within or } \\
\text { outside } \\
\text { China }\end{array}$ & Age & Examples & References \\
\hline \multirow[t]{2}{*}{ Marine } & Outside & Mesozoic and Cenozoic & $\begin{array}{l}\text { Silurian Saline A-1 unit of the } \\
\text { Michigan Basin; Devonian of } \\
\text { western Canada; Jurassic of the } \\
\text { Pakistan Basin and Middle East; } \\
\text { Jurassic of the Gulf of Mexico; } \\
\text { Lower Cretaceous of the South } \\
\text { Florida Basin; Upper Cretaceous } \\
\text { Eagle Ford Group of Texas; Upper } \\
\text { Cretaceous Laluna Formation of } \\
\text { Columbia; and the Miocene of } \\
\text { Sicily Basin }\end{array}$ & $\begin{array}{l}\text { Palacas et al. (1983), Zumberge } \\
\text { (1984), Edman and Pitman (2010) }\end{array}$ \\
\hline & Within & $\begin{array}{l}\text { Proterozoic, Paleozoic, and Meso- } \\
\text { zoic }\end{array}$ & $\begin{array}{l}\text { Paleozoic of the mid-western } \\
\text { Sichuan, Ordos, and Tarim basins; } \\
\text { Mesozoic of Tibet }\end{array}$ & Wang et al. (2013), Liu et al. (2017) \\
\hline \multirow[t]{2}{*}{ Lacustrine } & Outside & Mesozoic and Cenozoic & $\begin{array}{l}\text { Paleogene Green River Formation of } \\
\text { the Uinta Basin; Lower Cretaceous } \\
\text { Toca Formation of the Congo Rift } \\
\text { Valley; Lower Cretaceous of the } \\
\text { Brazilian Campos Basin; Cambrian } \\
\text { Observatory Hill Formation of the } \\
\text { Officer Basin }\end{array}$ & $\begin{array}{l}\text { Stank et al. (1992), Harris et al. } \\
\text { (2004) }\end{array}$ \\
\hline & Within & Paleozoic, Mesozoic and Cenozoic & $\begin{array}{l}\text { Paleogene Shahejie Formation of } \\
\text { the Bohai Bay Basin; Paleogene } \\
\text { of the western Qaidam Basin; } \\
\text { Paleogene Hetaoyuan Formation of } \\
\text { the Biyang sag, Nanxiang Basin; } \\
\text { and Lower Cretaceous Xiagou and } \\
\text { Chijinbao Formations of the Jiuxi } \\
\text { Basin }\end{array}$ & Wang et al. (2010), Tian et al. (2014) \\
\hline
\end{tabular}

Table 2 Overview of the sedimentary environments associated with the development of different types of carbonate source rocks (adapted from Oehler 1984; Zumberge 1984)

\begin{tabular}{|c|c|c|}
\hline Types of sedimentary environment & Characteristics & Examples \\
\hline $\begin{array}{l}\text { Subtidal to supratidal, low energy, and high- } \\
\text { salinity shelves }\end{array}$ & $\begin{array}{l}\text { Low energy, high salinity, including } \\
\text { intertidal flats, evaporative embay- } \\
\text { ments, and coastal sabkhas }\end{array}$ & $\begin{array}{l}\text { Upper Jurassic Smackover Formation, Gulf of } \\
\text { Mexico; Lower Cretaceous Sunniland Formation } \\
\text { in South Florida; and Silurian Saline A-1 unit of } \\
\text { the Michigan Basin }\end{array}$ \\
\hline $\begin{array}{l}\text { Evaporitic playa lakes surrounded by low topog- } \\
\text { raphy }\end{array}$ & $\begin{array}{l}\text { Limited terrigenous input, and hydro- } \\
\text { static bottom environment caused by } \\
\text { stratification of water mass }\end{array}$ & $\begin{array}{l}\text { Cambrian Observatory Hill Formation within the } \\
\text { northeastern Officer Basin; central Australia } \\
\text { and the Paleogene Green River Formation in the } \\
\text { Parachute Creek Basin }\end{array}$ \\
\hline Broad and low-relief carbonate shelves & Broad and low relief & $\begin{array}{l}\text { Upper Jurassic Callovian and Oxfordian of Saudi } \\
\text { Arabia and Jurassic Naokelekan Formation in } \\
\text { Iraq, Middle East }\end{array}$ \\
\hline Deep-water marlstones & Closely related to oil and gas reservoirs & $\begin{array}{l}\text { Permian of the Delaware Basin, and Permian } \\
\text { Zechstein Formation in eastern Germany }\end{array}$ \\
\hline
\end{tabular}

\subsection{Basic geochemistry of carbonate source rock}

\subsubsection{Organic matter abundance}

Organic matter abundance, as represented by total organic carbon (TOC), of carbonate source rock has a large variation. Gehman (1962) reported that TOC of limestones was low to $0.24 \%$, about one-quarter of that of shales, based on 346 limestones and 1066 shales in 60 representative basins aged from Precambrian to Tertiary. This understanding has 

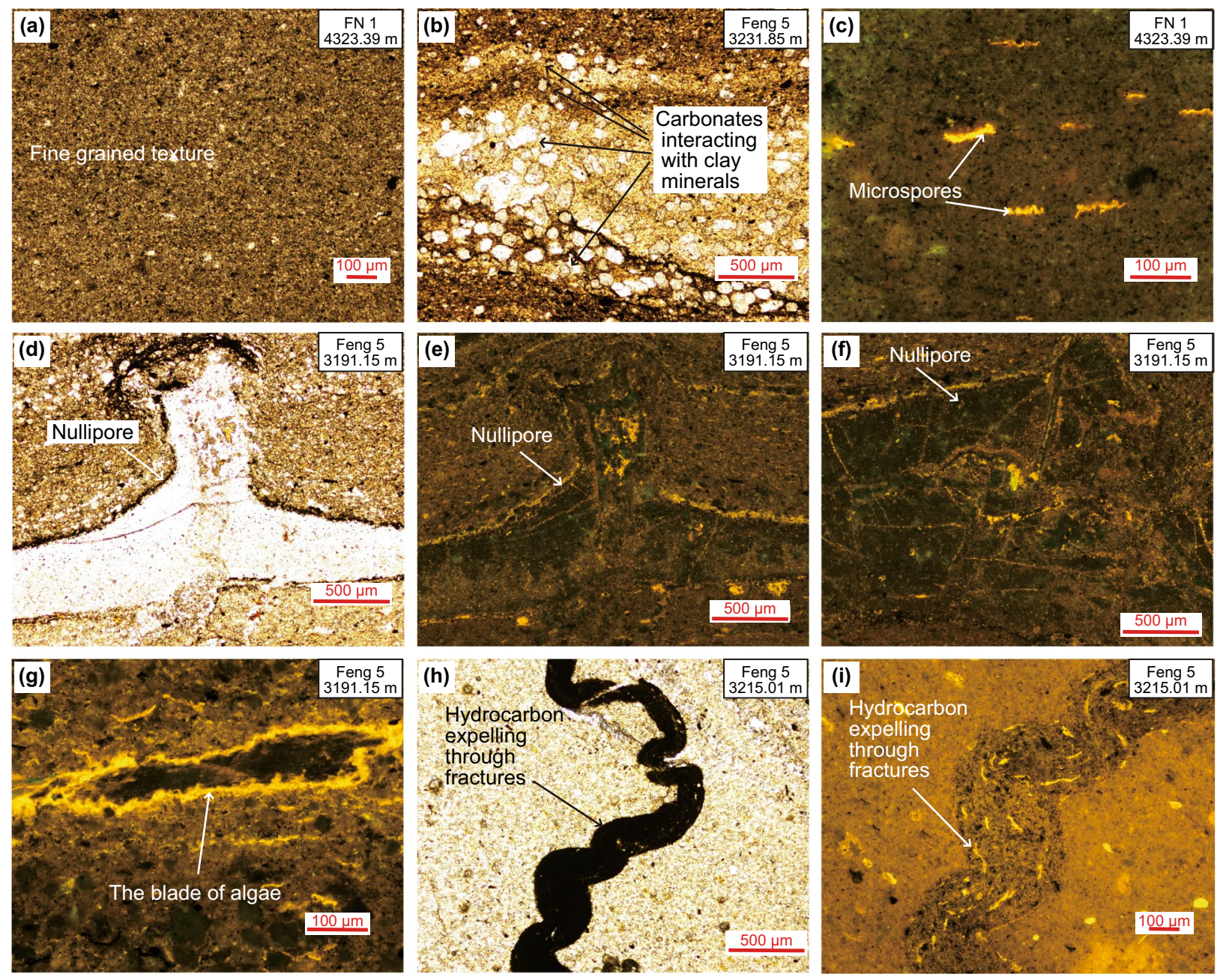

Fig. 2 Microphotographs showing the textures and bioprecursors of carbonate source rock in the lower Permian Fengcheng Formation within the Mahu sag (northwestern Junggar Basin, NW China), including a model of hydrocarbon expulsion through the fracturing of carbonate source rocks

been revised by later studies. It was found that the TOC of marine or lacustrine carbonate source rocks could be as high as or even higher than that of argillaceous source rocks. For example, the TOCs of the Paleogene Green River Formation in the Uinta Basin, the Lower Cretaceous Sunniland Formation in the South Florida Basin, and the Jurassic Tuwaiq Mountain Formation in Saudi Arabia are 1.0\%-20.0\%, $0.4 \%-3.0 \%$, and $1.1 \%-13.2 \%$, respectively (Tissot et al. 1978; Palacas et al. 1984; Hakami et al. 2016).

As for the marine carbonate source rocks, most have a good type of organic matter prone to oil generation, TOC has a negative correlation with thermal evolution and can be reduced by up to $80 \%$ for type I kerogen by maturation (Daly and Edman 1987; Jarvie 2014). For example, marine carbonate source rocks of the Middle Triassic Besano Formation in the Southern Alps, Italy, dominated by limestones and marls, have TOCs which reduce from $35.0 \%$ to $1.0 \%$ with $R_{\mathrm{o}}$ rising from $0.4 \%$ to $3.3 \%$ (Katz et al. 2000). In China, marine carbonate source rocks are mostly highly mature to over mature and thus contain generally a low abundance of organic matter $(\mathrm{TOC}=0.1 \%-1.0 \%$; Li 2005).

Lacustrine carbonate source rocks have highly variable organic matter abundance. For example, the Paleogene lacustrine carbonate source rocks in the western Qaidam Basin have generally low organic matter abundance (TOC generally $<0.4 \%$; Su et al. 2006; Wang et al. 2009). However, the Paleogene lacustrine carbonate source rocks of the Green River Formation in the Uinta Basin (USA) and the Hetaoyuan Formation in the Biyang sag (China) contain relatively high amounts of organic matter with TOC ranging at $1.0 \%-20.0 \%$ and $0.5 \%-7.6 \%$, respectively (Tissot et al. 1978; Tuo et al. 1997; Burton et al. 2014). This may reflect that complex factors influence the variability of organic matter abundance of these source rocks. The diagenesis of carbonate rocks, processes such as dolomitization and microbial effects, can affect organic matter abundance. 
For example, the dolomitization of stromatolitic limestones can replace organic matter within algal mats, reducing the amount of organic matter within these rocks. In addition, aerobic bacteria within oxygenated layers can decompose the majority of the organic matter within rocks, and methanogens within anaerobic layers can consume $\mathrm{CO}_{2}$ and free hydrogen to produce methane. This implies that numerous complex factors can affect organic matter abundance within carbonate source rocks.

The relatively low organic matter abundance within Chinese carbonate source rocks means that the lower limits of this abundance are critical for evaluating the hydrocarbon generation potential of these rocks as well as the exploration potential, as exemplified by a number of in-depth studies (Zhang et al. 2002; Cheng 2007; Huo et al. 2016). Combining thermal simulation studies of petroleum generation with actual exploration results, it is proposed that the lower prospective limit of organic matter abundance within carbonate source rocks is commonly lower than $0.5 \%$ TOC (Palacas 1983), and even as low as $<0.2 \%$ TOC (Fu and Jia 1989). This is remarkably lower than that for potential argillaceous source rocks as 1.0\% TOC (Bissada 1982; Katz and Lin 2014) or 0.5\% TOC (Peters and Cassa 1994), although further research is needed in this area.

\subsubsection{Types of organic matter}

As outlined above, carbonate source rocks are generally formed in hydrostatic environments. This means that these rocks contain bioprecursors that lack contribution of terrestrial organic matter and are dominated by bacteria and algae along with minor amounts of animal organic debris, in turn leading to type I and II kerogen in general with more of type II. As a result, carbonate source rocks can generate significant volumes of liquid hydrocarbons in the immature to early stages of thermal maturity due to the uniqueness of their bioprecursors (Tissot and Welte 1984). For example, marine carbonate source rocks of the Middle Jurassic Tuwaiq Mountain Formation in Saudi Arabia (Middle East), which are the main source rocks of the Ghawar Oil Field, the world's largest conventional oil field, contain type I to type II kerogen in limestones and calcareous mudstones (Hakami et al. 2016; Peng and Cantrell 2016). In China, Fu and Jia (1989) suggested that Neoproterozoic to Devonian marine carbonate source rocks contain type I kerogen, whereas carbonate source rocks deposited after the Carboniferous contain mixed kerogen as a result of increased terrestrial inputs.

The kerogen types of lacustrine carbonate source rocks have similar features. For example, the lower Permian Fengcheng Formation in the Mahu sag, northwestern Junggar Basin of NW China, contains type I to II kerogen and is associated with oils derived mainly from algae. These rocks contain numerous microspores that fluoresce (Fig. 2c) as well as coral algae within dolomitic source rocks (Fig. 2d-f) and macroscopic benthic algae leaves (Fig. $2 \mathrm{~g}$ ) that represent residues after hydrocarbons generated from algal bioprecursors. As for the occurrence form and distribution of organic matter, bacteria occur mainly as disseminations in the rocks. Planktonic algae are present mostly in amorphous forms that are dispersed in carbonates due to the alteration of bacteria, or they could have a lamellar occurrence. Benthic algae are characterized by leaf or grid-cell structures. These features would directly affect the hydrocarbon generation and expulsion capabilities of carbonate source rock.

In summary, carbonate source rocks contain higher amounts of oil-generating materials than argillaceous source rocks containing the same amount of organic carbon (Hunt and McNichol 1984), thereby highlighting the oil generation potential of carbonate rocks.

\subsubsection{Organic matter maturity}

As noted above, carbonate source rocks contain organic matter that is dominated by bacteria and algae, which means that they generally lack vitrinites. Consequently, the maturity of these source rocks cannot be easily estimated using traditional methods based on vitrinite reflectance $\left(R_{\mathrm{o}}\right)$, meaning that a number of indirect approaches have been used. For example, (1) Feng and Chen (1988) determined that bitumen reflectance $\left(R_{\mathrm{b}}\right)$ values can be converted to vitrinite reflectance values using parameters derived from laboratory-based thermal simulation experiments that yielded the following equation: $R_{\mathrm{O}}=0.3154+0.0679 R_{\mathrm{b}}$. (2) The maturity of carbonate source rocks can be estimated using the color of kerogen, spores, pollens, conodonts, acritarchs, and chitinozoans (Cordell et al. 1992; Wang 1993), especially the well-known conodont alteration index (CAI; Epstein et al. 1977). A comparative study by Qi et al. (1998), who compared CAI and $R_{\mathrm{o}}$ values in adjacent sedimentary layers, yielded a regression equation as follows: $R_{\mathrm{o}}=0.6175 \mathrm{CAI}-0.1832$ (with a correlation coefficient $R$ of 0.99 ). (3) Organic matter maturity can also be estimated using biomarker characteristics such as $T_{\mathrm{s}} / T_{\mathrm{m}}$ ratios, the $22 \mathrm{~S} / 22 \mathrm{R}$ ratios of $\mathrm{C}_{31}-\mathrm{C}_{35}$ hopanes, and the $20 S /(20 \mathrm{~S}+20 \mathrm{R})$ ratios of $\mathrm{C}_{29}$ steranes (Cordell et al. 1992), although all of these biomarkers can be effectively used in mature stages.

\subsubsection{Molecular geochemistry}

Jones (1984) compared biomarkers within carbonate and shale source rocks and determined that the former and their generated crude oils have the following four key characteristics. (1) They contain high concentrations of sulfur compounds, suggesting that bacteria may have reduced sulfate to produce $\mathrm{H}_{2} \mathrm{~S}$ gas. This may have increased the sulfur content of the source rocks during carbonate diagenesis, and the 
sulfur become bound into generated crude oils. (2) They are characterized by low $\mathrm{Pr} / \mathrm{Ph}$ ratios, reflecting their formation in reducing depositional environments. (3) They contain $\mathrm{C}_{18}-\mathrm{C}_{30}$ alkanes that have an even to odd carbon preference, which might imply some special bioprecursors. (4) Finally, they have lower diasterane abundances relative to sterane, which might imply some special bioprecursor compositions or less clay minerals in carbonate source rocks. In addition, Palacas et al. (1983) and Moldowan et al. (1985) summarized other carbonate source rock biomarker characteristics, including relatively high heteroatom (NSOs) and resin contents, high aromatic hydrocarbon contents in hydrocarbons, higher sterane and terpene contents relative to alkane contents, and high benzothiophene contents in hydrocarbons.

Taking the research into Chinese Paleozoic marine carbonate source rocks as examples, Cheng et al. (1996) summarized the characteristics of their biomarkers as follows. (1) They have a single peak distribution of $n$-alkanes with a low main carbon peak and a clear even to odd carbon preference. (2) They also contain regular and irregular $\mathrm{C}_{21}-\mathrm{C}_{25}$ acyclic isoprene alkanes derived from cyanobacteria and archaea. (3) These source rocks also generate $\mathrm{C}_{31}-\mathrm{C}_{35}$ long side-chain tricyclic terpanes within bacterial and algal cell membranes, and $\mathrm{C}_{31}-\mathrm{C}_{35}$ homohopanes that are controlled by salinity conditions. (4) These source rocks did not contain significant amounts of pregnanes but these compounds were concentrated in the generated crude oils. (5) $\mathrm{C}_{29}$ steranes are present in higher concentrations than $\mathrm{C}_{27}$ and $\mathrm{C}_{28}$ steranes and are derived from algae during the Paleozoic rather than from higher plants.

\subsubsection{Organic facies}

Organic facies refer to specific rock assemblages that have certain organic matter abundance, type, source, and depositional environment (Rogers 1979). These facies are divided into four types A-D in general, mainly based on kerogen $\mathrm{H} / \mathrm{C}$ ratio at $R_{\mathrm{o}}$ of $\sim 0.5 \%$ and pyrolysis parameters like $\mathrm{HI}$ and OI, whose representative depositional and organic geochemical characteristics are summarized in Tables 3 and 4. In particular, organic facies A is preferentially associated with carbonate source rocks as a result of the lack of terrestrial organic matter inputs relative to argillaceous source rocks. This may also reflect inorganic hydrogeneration in alkaline lacustrine environments, e.g., the well-known Green River Formation (Jones 1984). However, the extremely special formation conditions of the organic facies A means that this type of source rock is relatively rare in the geological record for both carbonate and mudstone/shale sedimentary units outside the Middle East.

In contrast, the majority of hydrocarbon source rocks worldwide are characterized by organic facies B, in a general view of both carbonate and argillaceous source rocks. Specifically, characteristics of this type of carbonate source rocks differ from argillaceous source rocks in that the former contains very little iron, meaning that carbonate source rocks contain more sulfur than argillaceous source rocks. With respect to organic facies $\mathrm{C}$, which is associated with continental depositional environments, it is more commonly associated with argillaceous source rocks. Finally, the majority of carbonate rocks are associated with organic facies D,

Table 3 Overview of the basic characteristics of organic facies A-D (Jones 1984)

\begin{tabular}{lllll}
\hline Organic facies & $\begin{array}{l}\text { Types of gener- } \\
\text { ated hydrocarbons }\end{array}$ & Sedimentary environment & Sedimentary structure & Organic matter \\
\hline A & Oil & Anoxic, lacustrine & Finely laminated & Algal, amorphous, rarely terrestrial \\
B & Oil & Anoxic, marine & Laminated, well bedded & Algal, amorphous, commonly terrestrial \\
B-C & Oil-gas & Varied, delta & Poorly bedded & Mixed marine and terrestrial \\
C & Gas & Mildly oxic, shelf or slope, coal & Poorly bedded, bioturbated & Terrestrial, mostly "vitrinites" \\
D & Dry gas & Highly oxic, anywhere & Massive, bioturbated & Highly oxidized, reworked \\
\hline
\end{tabular}

Table 4 Overview of the geochemical characteristics of organic facies A-D (Jones 1984)

\begin{tabular}{lllll}
\hline Organic facies & Types of generated hydrocarbons & $\begin{array}{l}\text { Atoms H/C of kerogen at } R_{\mathrm{o}} \\
\text { of } \sim 0.5 \%\end{array}$ & Pyrolysis parameters \\
\cline { 4 - 5 } & & & HI & $700->1000$ \\
A & Oil & $\geq 1.4$ & $350-700$ & $10-40$ \\
B & Oil & $1.2-1.4$ & $200-350$ & $20-60$ \\
B-C & Oil-gas & $1.0-1.2$ & $50-200$ & $50-80$ \\
C & Gas & $0.7-1.0$ & $<50$ & $20-200$ \\
D & Dry gas & $0.4-0.7$ & & 50 \\
\hline
\end{tabular}



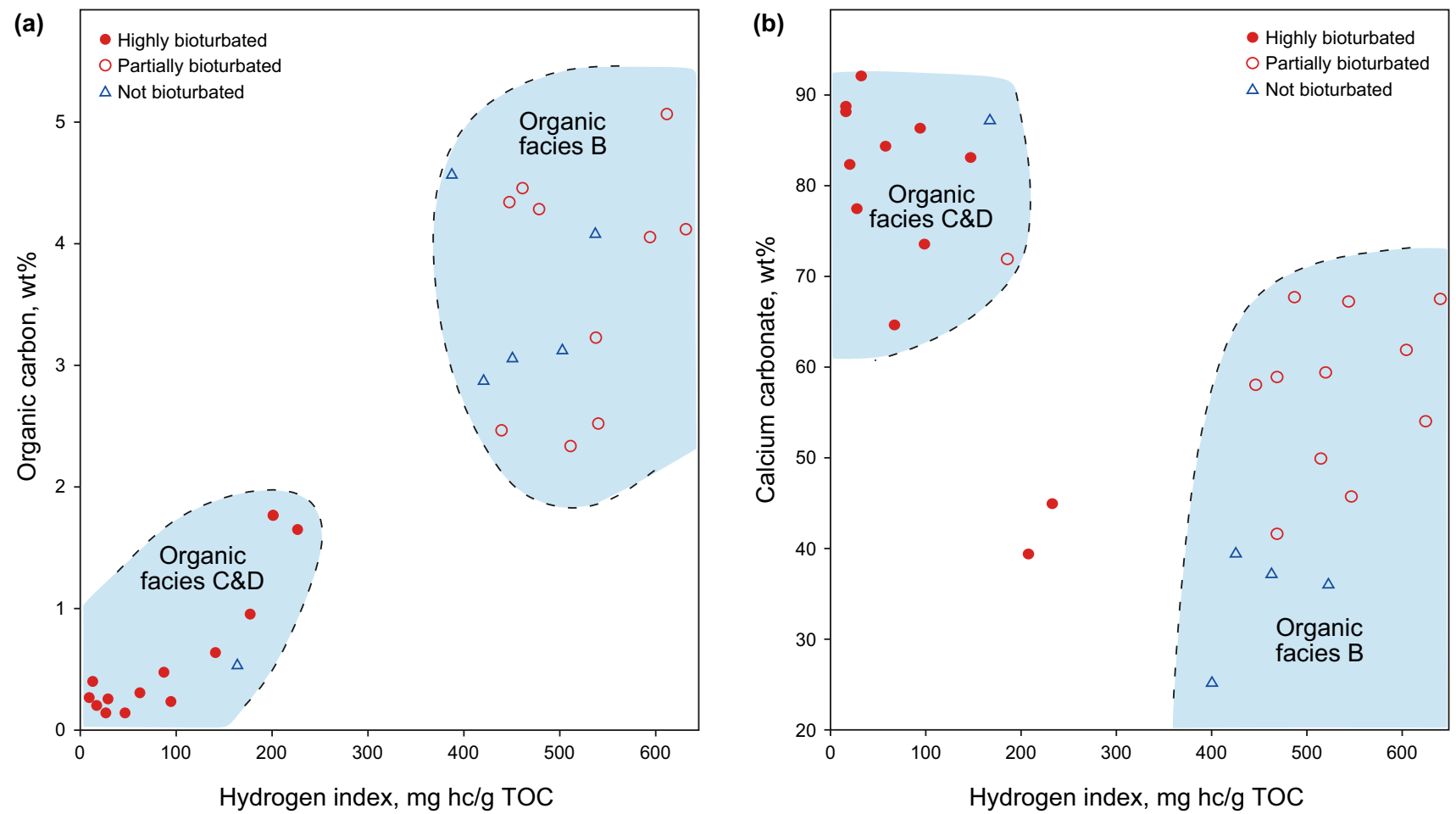

Fig. 3 Correlations between hydrogen index and contents of organic carbon (a) and calcium carbonates (b), the Cretaceous Greenhorn Formation in Colorado, USA (after Pratt 1982)

primarily as a result of these rocks being slowly deposited in an oxidized shallow water mass. This implies that these rocks generally have low hydrocarbon generation potential as a result of forming in strongly oxidized environments (Larskaia 1977).

An overview of the characteristics of different organic facies can be exemplified by the Cretaceous Greenhorn Formation in Colorado, including the correlations between organic carbon, calcium carbonate, and hydrogen index values (Fig. 3; Pratt 1982). Note that the rarity of organic facies A in the geological record means it is absent in these figures. However, this type of organic facies has large oil generation potential, e.g., the Eocene Green River Formation in the Uinta Basin, USA (Tissot et al. 1978; Zhang et al. 2009; Burton and Sullivan 2014).

\section{Hydrocarbon generation of carbonate source rock}

\subsection{Characteristics and models of hydrocarbon generation}

As presented above, carbonate source rocks vary largely from traditional argillaceous source rocks in terms of lithology and geochemistry. As a result, the hydrocarbon generation is expected to be different. However, this issue has not been well studied because produced oils in most cases are a mixture derived both from carbonate and from argillaceous source rocks, as outlined above (Lü et al. 2017). Thus, the majority of research into hydrocarbon generation of carbonate source rock is mainly based on thermal simulation experiments. Based on the experimental data from the Ordos, Gansu, Sichuan, Tarim, and North China areas, Wang and Cheng (1997) proposed a three-stage hydrocarbon generation model for carbonate source rocks. The first stage is characterized by the depolymerization of biological macromolecules to form immature oil. The second stage is associated with the pyrogenic generation of hydrocarbons from a significant amount of kerogen within the source rocks. The final stage is associated with late and post-thermal maturity where organic matter included in minerals is released (Fig. 4). This is the same as that of traditional argillaceous source rocks, but the products, yields, and sources of hydrocarbon are obviously different in each stage, especially in the first and third stages. The majority of hydrocarbons are generated during the second stage of thermal maturity as a result of kerogen degradation. However, biological macromolecules derived from bacteria and algae can also depolymerize to form a considerable amount of immature oil during the first stage of evolution of carbonate source rock; in contrast, the immature oil sourced from traditional 


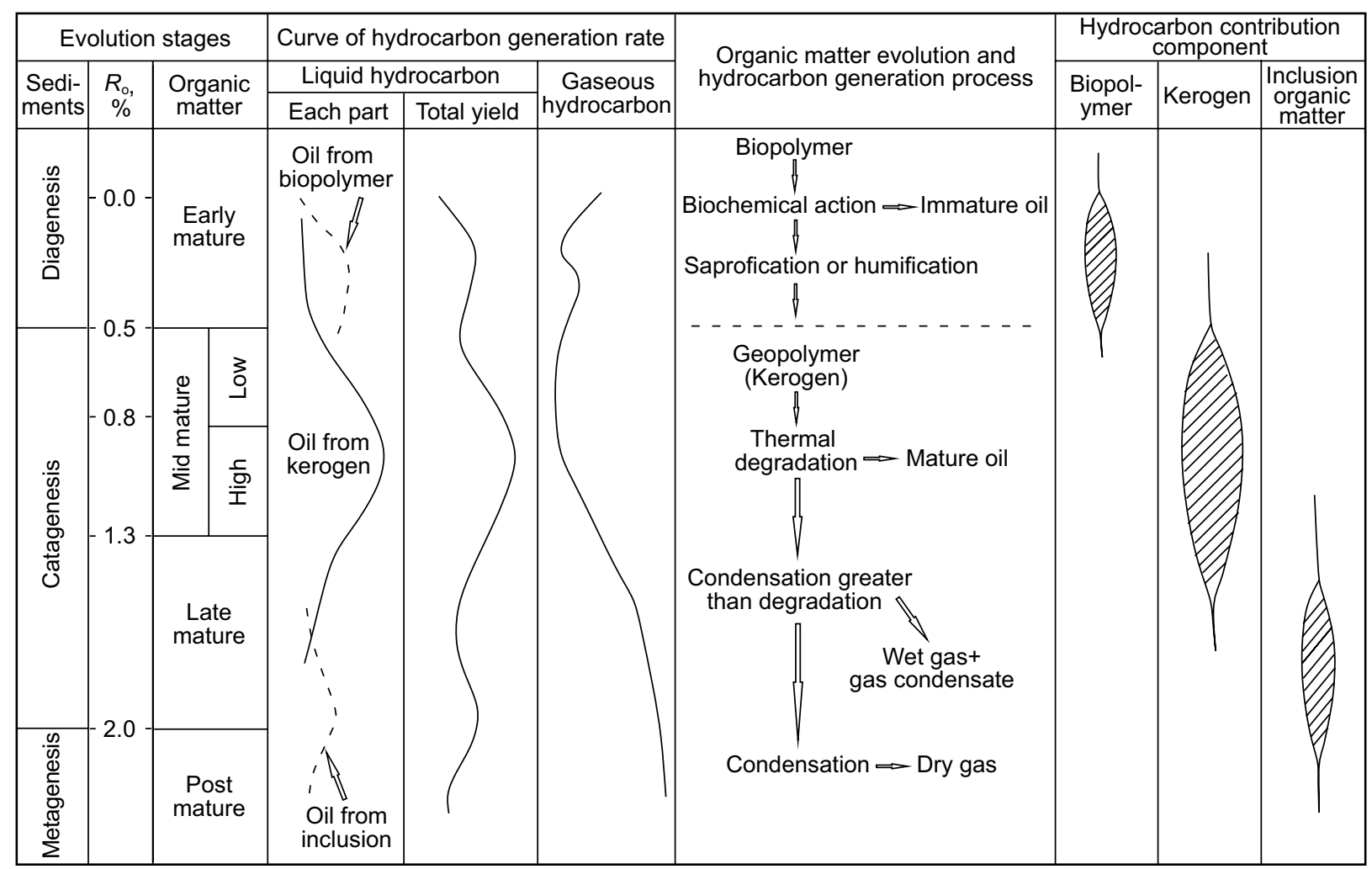

Fig. 4 Thermal evolution model for the generation of hydrocarbons from carbonate source rocks (after Wang and Cheng 1997)

argillaceous rocks is extremely limited. In addition, the third stage of the evolution of argillaceous source rocks generates wet gas and condensate oil, whereas carbonate source rocks release liquid hydrocarbons derived from included organic matter. This indicates that carbonate source rocks can generate liquid hydrocarbons over a wider range of thermal maturity than argillaceous source rocks. This is one of critical differences between these two types of source rocks.

Notably, the three-stage hydrocarbon generation model for carbonate source rocks above is based on a comprehensive analysis of samples from marine, lacustrine, and marine-terrigenous carbonates. However, the actual hydrocarbon generation models for these different carbonates also have their own characteristics. For example, Huang and Lv (2011) compared marine carbonate source rocks of the upper Permian Wujiaping Formation of the Sichuan Basin (Fig. 5a) with argillaceous source rocks of the Eocene of the Nanxiang Basin (Fig. 5b). Comparative results indicate that these marine carbonate source rocks yielded significant amounts of liquid hydrocarbons but relatively low amounts of gaseous hydrocarbons. In addition, compared with argillaceous source rocks, the carbonate source rocks have a peak period of oil production that is earlier, but a gaseous hydrocarbon peak that is unclear and maybe later than is the case for argillaceous source rocks.
Ma et al. (2012a, b) undertook pyrolysis simulation experiments on lacustrine mudstone and argillaceous dolomite source rocks of the Cretaceous Zhonggou Formation, within the Qingxi Sag of the Jiuxi Basin, NW China, to compare the hydrocarbon generation model of these lacustrine carbonate source rocks with more typical argillaceous source rocks (Fig. 6). Results show that the petroleum-generating capacity of these lacustrine argillaceous dolomites is higher than that of the argillaceous source rocks in this area. These carbonate source rocks also have later liquid and gaseous hydrocarbon generation peaks than those of the argillaceous source rocks, indicative of a late hydrocarbon generation characteristic.

These studies indicate similarities and differences in oil and gas productivity, and the peaks of oil and gas generation between the marine and lacustrine carbonate and argillaceous source rocks. Marine and lacustrine carbonate source rocks have higher oil productivities than mudstones or dolomitic mudstones, as well as later gaseous hydrocarbon production peaks (Table 5). In addition, less gas is produced from marine carbonates than mudstones (Huang and $\mathrm{Lv}$ 2011), but more gas is produced from lacustrine carbonates than dolomitic mudstones (Ma et al. 2012a, b). Finally, the timing of peak oil generation from marine carbonates is earlier than is the case for argillaceous source rocks (Huang 
(a)

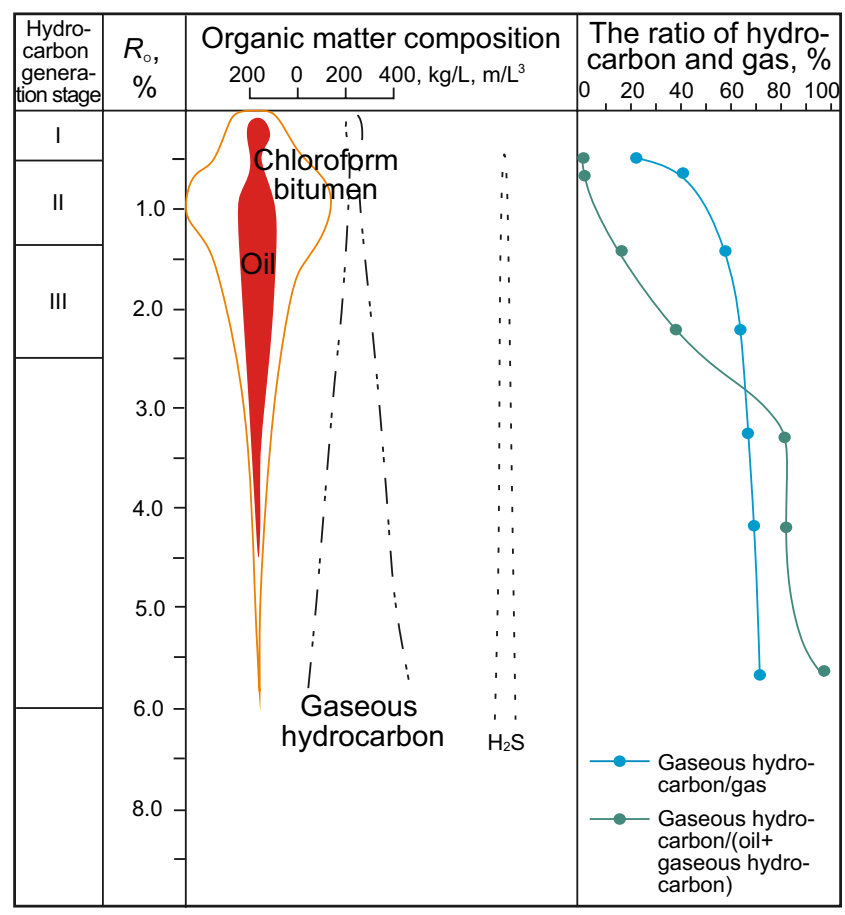

(b)

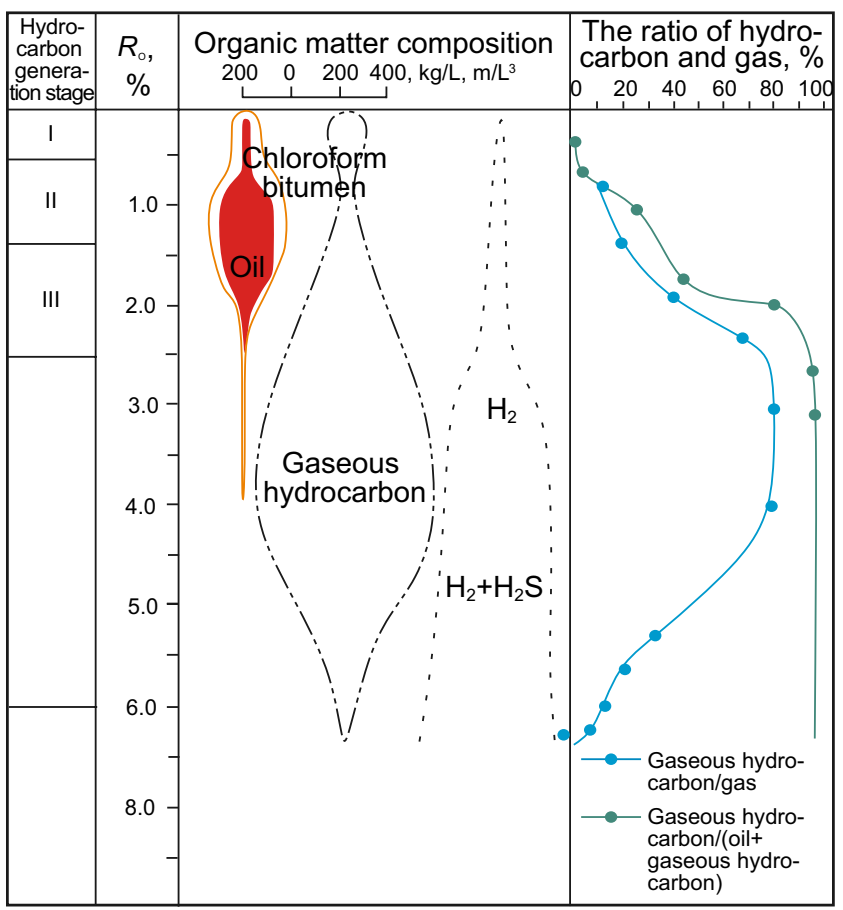

Fig. 5 Hydrocarbon generation models for marine carbonate and lacustrine argillaceous source rocks (after Huang and Lv 2011). a Marine carbonate source rocks of the upper Permian Wujiaping Formation, Sichuan Basin, China; b Argillaceous source rocks of the Eocene Hetaoyuan Formation, Nanxiang Basin, China

(a)

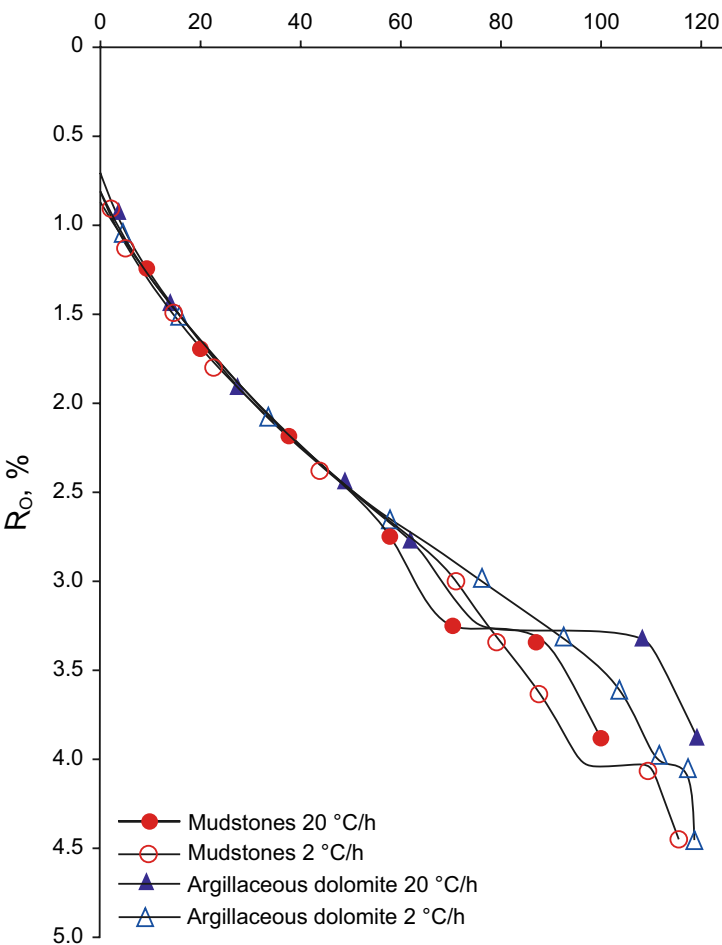

(b) Production of oil, \%

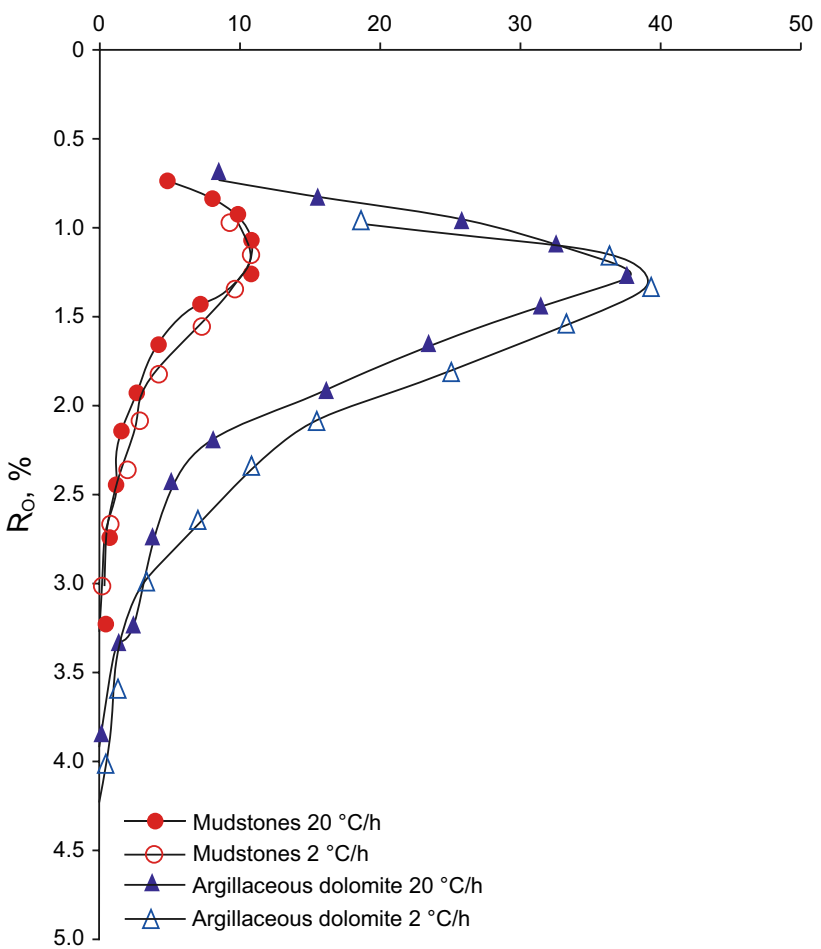

Fig. 6 Characteristics of hydrocarbon generation along with maturity $\left(R_{\mathrm{o}}\right)$ of lacustrine mudstones and muddy dolomites in the Jiuxi Basin, NW China (after Ma et al. 2012a, b). a Generation volume of $\mathrm{CH}_{4}$; b Generation volume of oil 
Table 5 Overview of hydrocarbon generation characteristics of marine and lacustrine carbonate source rocks compared with argillaceous source rocks

\begin{tabular}{|c|c|c|}
\hline Source rocks & Marine carbonate source rocks in Sichuan Basin & $\begin{array}{l}\text { Lacustrine carbonate source rocks } \\
\text { in Jiuxi Basin }\end{array}$ \\
\hline Comparison & Mudstones in Nanxiang Bain & Dolomitic mudstones in Jiuxi Basin \\
\hline Yield of oil & Higher than mudstones & Higher than dolomitic mudstones \\
\hline Yield of gas & Lower than mudstones & Higher than dolomitic mudstones \\
\hline Peak of oil generation & Earlier & Later \\
\hline Peak of gas generation & Unclear, later & Later \\
\hline Reference & Huang and Lv (2011) & Ma et al. $(2012 a, b)$ \\
\hline
\end{tabular}

and Lv 2011), whereas the opposite is true for lacustrine carbonates (Ma et al. 2012a, b).

In summary, the characteristics and models of hydrocarbon generation from carbonate source rocks are still not sufficiently known. This can be ascribed to multiple possible reasons. For example, samples vary between studies. Unlike Ma et al. (2012a, b) who compared lacustrine carbonates with dolomitic mudstones in the Jiuxi Basin, Huang and LV (2011) compared marine carbonates in the Sichuan Basin with mudstones in another basin. This may lead to confusion due to different geological settings, e.g., organic bioprecursors and maturity, and mineral compositions. Sedimentary environment is another important control. Forming in saline environments, marine carbonates contain plentiful sulfur that may help an early oil generation because of easy breakage of $\mathrm{S}-\mathrm{C}$ bonds. In addition, catalysis by minerals might have an important impact on the timing of hydrocarbon generation, and thus, different lithological source rocks would have different evolution histories of hydrocarbon generation (Geatches et al. 2010). Further research is needed to fully understand these complex and seemingly contradictory differences in hydrocarbon generation.

\subsection{Mechanism of hydrocarbon generation}

The unique hydrocarbon generation characteristics of carbonate source rocks as discussed above have been interpreted as being a result of the heterogeneous and complex hydrocarbon generation caused by diverse organic matter within these sediments (Cheng et al. 1996). Organic matter within carbonate source rocks is both aggregated and disseminated and can be classified into three categories as follows (Fu and Jia 1984). (1) Adsorbed organic matter that is adsorbed onto the surfaces of minerals or rocks and is easy to release, including void-filling, amorphous, and debris-type organic matter. Cheng et al. (1996) further divided void-filling organic matter into fracture, biological void, crystal void, geode, intergranular, and stylolite types of filling. (2) Mineral-enclosed-type organic matter that is not easy to release is present within generally aphanitic or microcrystalline minerals, including intergranular combined, floc, and disseminated types of organic matter that does not migrate but represents protogenetic organic matter instead. (3) Organic matter hosted by inclusions within crystalline minerals that is large but is not easy to release. The main difference between crystal-enclosed and inclusion-hosted organic matter is that the first has not migrated but is protogenetic, whereas the latter has migrated and is secondary.

The presence of these different types of organic matter is responsible for the unique three-stage model of hydrocarbon generation in carbonate source rock. The immature stage of this model is characterized by the depolymerization of lipid-rich biomacromolecules that are either aggregated or dispersed within the carbonate source rocks to form immature to early mature oil, which may also be related to the relatively high content of bitumen associated with good oil-prone types of organic matter, compared with that of argillaceous source rocks (Cordell 1992). The middle stage of maturity is associated with pyrogenic hydrocarbon generation from a significant proportion of the kerogen within the source rocks. The later final stage of thermal maturity is associated with the release of partially liquid hydrocarbons from crystal- and inclusion-hosted organic matter.

\subsection{Hydrocarbon expulsion}

Hydrocarbons start to be expelled and to migrate from source rocks after generation. Many studies have examined the expulsion and migration of hydrocarbons from carbonate source rocks (Jones 1984; Cordell et al. 1992; Cheng et al. 1996). Jones (1984) suggested that the main differences in hydrocarbon expulsion between carbonate and argillaceous source rocks are the result of differences in physical properties. In general, carbonate source rocks are relatively brittle, heterogeneous, and compact compared with argillaceous source rocks, meaning that the former are more prone to rupture and the hydrocarbons are easier to expel. This suggests that oil and gas can migrate from carbonate rocks explosively under certain geological conditions, as exemplified in the world's largest oilfield, Ghawar. Hydrocarbon expulsion 
and migration from source rocks containing high concentrations of organic matter under high-temperature conditions in a passive structural environment are limited as a result of a decrease in permeability. However, tectonic disruption of these rocks can lead to the explosive expulsion and migration of hydrocarbons and the release of a significant amount of oil and gas to reservoirs.

Close attention has been paid to the effects of physical compaction and stylolitization on hydrocarbon expulsion during the diagenesis of carbonate rocks (Cordell et al. 1992; Jia et al. 2016). For example, the fact that the physical compaction of carbonate rocks generally takes place at depths shallower than $300 \mathrm{~m}$ (i.e., far from the oil window) means that the accompanying cementation, crystallization, and recrystallization act to inhibit this physical compaction. Consequently, physical compaction does not affect the expulsion of hydrocarbons from carbonate rocks, a significant difference when compared with argillaceous source rocks. In addition, organic matter within carbonate source rocks often migrates along stylolites formed by chemical compaction, a process that can also facilitate the lateral migration of oil and gas. Cordell et al. (1992) also stressed that oil and gas can only continuously migrate along layers or stylolites within stratified or stylolite-bearing carbonate rocks. The majority of cases have oil-bearing layers that are separated by aquifers, meaning that microcracks or larger fractures act as the main migration channels for oil and gas.

Cheng et al. (1996) used hydrocarbon generation simulations to summarize the characteristics of petroleum migration and expulsion within immature carbonate source rocks as follows. (1) Hydrocarbon generation in carbonate source rocks occurs early but produces oil that is generally sealed within the source rocks rather than expelled. (2) The timing of significant hydrocarbon expulsion is dependent on brittle deformation of source rock as a result of external forcing rather than physical compaction, a process that dominates the expulsion of hydrocarbons from argillaceous source rocks. (3) Carbonate source rocks can discharge liquid hydrocarbons during the late stages of maturity. These hydrocarbons are derived from crude oil preserved by inclusions within carbonate minerals that formed before the source rocks entered the upper limits of the oil window.

These types of hydrocarbon expulsion are illustrated by the lower Permian Fengcheng Formation in the Mahu sag (Fig. 2h-i). Here, hydrocarbons were expelled from carbonate source rocks as a result of brittle deformation caused by external forces that generated fractures and stylolites. This is illustrated by the fractures developed in micritic dolomites that are shown in Fig. $2 \mathrm{~h}-\mathrm{i}$, where black residual organic matter within these fractures is shown under plane-polarized light in Fig. 2h. These sediments also contain asphaltenes that barely fluoresce and highly fluorescent organic matter fragments as residual hydrocarbons along the fractures
(Fig. 2i), thereby indicating the importance of brittle fracturing to the expulsion of hydrocarbons from these source rocks.

\section{Research prospects}

Based on the above discussion, it can be concluded that the geochemistry and hydrocarbon generation characteristics of carbonate source rock are different from those of traditional argillaceous source rock and are understudied due to the complexity. However, these need to be investigated as carbonate source rocks are widely developed and play important roles in hydrocarbon accumulation. Thus, to improve the understanding of these critical issues, we outline several key areas for future research that can also aid in future hydrocarbon exploration.

\section{(1) Effectiveness of carbonate source rocks}

The effectiveness of carbonate source rocks remains a controversial topic. For example, Cordell et al. (1992), Katz et al. (2000), and Huang and Lv (2011) suggested that these rocks could be effective hydrocarbon sources relative to argillaceous source rocks. However, the fact that carbonate rocks generally develop in open and oxygenated water bodies means that the original bacterial and algal organic matter may decompose, a process that is not conducive to hydrocarbon generation. Degens (1964) suggested that carbonates are generally poor hydrocarbon source rocks that rarely generate economic hydrocarbon resources.

In addition, carbonate sedimentary sequences often contain both argillaceous and carbonate components in variable proportions, meaning that understanding variations in the contribution of argillaceous and carbonate source rocks to hydrocarbon resources is important but challenging. For example, Yurchenko et al. (2018) confirmed the presence of two genetically distinct organofacies, namely "calcareous" and "shaly" end members. They analyzed oil families in the Triassic Shublik Formation, Alaska North Slope, by using oil-source rock correlation. Multiple methods were used, including chemometric evaluation of multivariate biomarkers, detailed comparison of mass chromatograms, individual biomarker ratios, and quantitative extended diamondoid analysis (QEDA). However, they did not characterize the mixing degrees between end-member oils, which is a key requirement for fully understanding the role of carbonate source rocks in hydrocarbon generation. In other words, if carbonate rocks are proven to contribute few to zero hydrocarbons to hydrocarbon reservoirs, there is no further requirement to study the source rock characteristics of these carbonates. In addition, the relationship between highquality source rocks and carbonate contents within them is 
complex, so it is not yet appropriate to rush to conclusions and more research is needed.

(2) Differences of marine and lacustrine carbonate source rocks

As discussed above, there are two end members for carbonate rocks, i.e., marine and lacustrine. For example, in China, in addition to the Paleozoic marine carbonate source rocks, there are also Mesozoic and Cenozoic lacustrine carbonate source rocks. Then, the characteristics of marine and lacustrine carbonate source rocks should be discussed and compared comprehensively, including the sedimentary petrology, sources of biogenic organic matter, geochemistry, source rock evaluation indicators, and hydrocarbon generation. However, these problems remain poorly understood because the previous works are not detailed or comprehensive. For example, natural gas and oil that might be related to carbonate source rocks are dominantly produced in the marine Sichuan and Ordos basins and the lacustrine Bohai Bay Basin, respectively. Whether bioprecursors and mineralogical components in addition to the thermal maturity of organic matter have impact on this hydrocarbon generation is not clear.

Some research has tried to decipher the differences between hydrocarbon generation of marine and lacustrine carbonate source rocks. For example, Huang and Lv (2011) and Ma et al. (2012a, b) compared the hydrocarbon generation characteristics of marine carbonate rocks, lacustrine argillaceous source rocks, lacustrine dolomitic mudstones, and lacustrine carbonate source rocks. However, the comparison was not conducted within one individual area and one individual stratigraphic sequence, which makes the results and understanding not very convincing as the bioprecursors, types and thermal evolution of organic matter and mineralogical compositions in these environments might be very different. Given that there are multiple sets of Mesozoic and Cenozoic potential lacustrine carbonate source rocks and Paleozoic and precambrian marine carbonate source rocks in China, the study of the differences of hydrocarbon generation between them needs more work.

In summary, although marine and lacustrine environments might generate similar carbonate sequences, the impact of changing environments on variations in specific lithologies and organic precursors, and the hydrocarbon generation characteristics should be noted and investigated in detail in the future.

(3) Effects of lithologies of carbonate source rocks on hydrocarbon generation

The previous research has examined the geochemistry and characteristics of hydrocarbon generation and expulsion of carbonate source rocks as discussed above. However, carbonate source rock sequences include various types of rocks, e.g., limestones, dolomites, and marls (Hang and Lv 2011). The lithological variations which might have important effects on hydrocarbon generation potential have received little attention. It remains unclear which types of carbonate rocks (limestones, dolomites, or marls) can act as source rocks, and the effect of variations in these lithologies on hydrocarbon generation characteristics and potential is poorly known. These are all critical in the study of carbonate source rocks.

(4) Bioprecursors and hydrocarbon generation models of carbonate source rocks

It is thought that hydrocarbons generated within carbonate source rocks are generally derived from bacteria and algae rather than terrestrial organic matter. However, the proportion of bacteria and algae species, including phytoplankton, benthic algae, bacteria, and archaea, remains unclear. In addition, it is known that the different modes of preservation of organic matter within carbonates act as a significant control on hydrocarbon generation processes, but the exact processes that cause these differences remain unclear. These (and potentially other) factors mean that carbonate rocks have unique hydrocarbon generation mechanisms. For instance, Fu and Jia (1984) and Ma et al. (2012a, b) reported that carbonates generate hydrocarbons at a later stage than argillaceous source rocks, whereas Zhao et al. (2005) and Huang and Lv (2011) argued the opposite, thereby highlighting the lack of a widely accepted hydrocarbon generation model for carbonate source rocks. In addition, it is unclear whether the mineralogy of these carbonate source rocks has any influence on hydrocarbon generation processes, including whether carbonate minerals catalyze or delay the generation of hydrocarbons.

\section{(5) Research methodology}

Like argillaceous source rocks, traditional source rock research methods have been widely used in the study of carbonate source rocks, including organic petrology, Rock-Eval pyrolysis, gas chromatography (GC), gas chromatography-mass spectrometry (GC-MS), and gas chromatography-mass spectrometry-mass spectrometry (GC-MS/MS).

Considering that carbonate source rocks have complex lithologies and bioprecursors, chemical compositional analyses have been applied, e.g., scanning electron microscopy (SEM), X-ray diffraction (XRD), electron probe microanalysis (EPMA), and laser Raman microspectroscopy (LRM) (Shang et al. 2018). In addition, as it is easier to expel hydrocarbons from carbonate source rocks than from argillaceous source rocks, improved simulation apparatus 
for hydrocarbon generation and expulsion has been developed, i.e., simulation in finite spaces under a high-pressure liquid medium (Ma et al. 2012a, b). Recently, Yurchenko et al. (2018) applied new geochemical methods based on QEDA to study the carbonate source rocks of the Triassic Shublik Formation, Alaska North Slope, USA. They determined the mixed oil types both from carbonate and argillaceous source rocks and established diamondoid signatures of source rock end members. In summary, more advanced methods need to be developed to meet the requirements of the study of carbonate source rocks, especially their hydrocarbon generation.

\section{Conclusions}

1. Carbonate rocks are an important type of hydrocarbon source rock, as exemplified by many cases, e.g., the South Florida Basin in the USA, the Ghawar oilfield in the Middle East, and the Jiuxi Basin in China.

2. These source rocks form in sedimentary environments characterized by low terrestrial inputs, high salinities, and low amounts of dissolved oxygen. They are dark gray to black, fine-grained, layered, and contain bacterial and algal residues as well as impurities. These source rocks contain generally low concentrations of organic matter, although these values can vary significantly in lacustrine environments. They contain type I and II kerogen, and the maturity of this organic matter is assessed by atypical means as a result of a lack of vitrinites. These source rocks have geochemical features characterized by high concentrations of sulfur compounds, low $\mathrm{Pr} / \mathrm{Ph}$ ratios, and $n$-alkanes that are dominated by even numbers of carbons, low concentrations of diasteranes, and benzothiophene containing high concentrations of thiophene sulfur. They also are dominated by B-type organic facies settings, with the exception of lacustrine carbonates that are dominated by A-type organic facies settings.

3. These source rocks generally have a three-stage hydrocarbon generation model that is influenced by complex bioprecursors and occurrence of organic matter including adsorbed, crystal-hosted and inclusion-hosted. The expulsion of hydrocarbons from these source rocks is dependent on brittle deformation as a result of external forces (e.g., tectonism).

4. Significant research is still needed in this area, including determining the effectiveness of hydrocarbon generation of different carbonates, exploring the differences of hydrocarbon generation between marine and lacustrine carbonate source rocks, further characterizing the lithologies of carbonate source rocks and the effects of variations in lithology on hydrocarbon generation, determin- ing the specific bioprecursors that form hydrocarbons, refining hydrocarbon generation models, processes, and mechanisms, and applying new methods to study carbonate source rocks.

Acknowledgements We thank anonymous reviewers for their constructive comments that helped improve this paper. This work was jointly funded by the National Science and Technology Major Project of China (Grant No. 2016ZX05003-005), and National Natural Science Foundation of China (Grant Nos. 41472100 and 41322017).

Open Access This article is distributed under the terms of the Creative Commons Attribution 4.0 International License (http://creativeco mmons.org/licenses/by/4.0/), which permits unrestricted use, distribution, and reproduction in any medium, provided you give appropriate credit to the original author(s) and the source, provide a link to the Creative Commons license, and indicate if changes were made.

\section{References}

Al-Khafaji AJ, Hakimi MH, Najaf AA. Organic geochemistry characterisation of crude oils from Mishrif reservoir rocks in the southern Mesopotamian Basin, South Iraq: implication for source input and paleoenvironmental conditions. Egypt J Pet. 2017;27(1):11730. https://doi.org/10.1016/j.ejpe.2017.02.001.

Bissada KK. Geochemical constraints on petroleum generation and migration—a review. Proc ASCOPE Conf. 1982;81:69-87.

Burton D, Woolf K, Sullivan B. Lacustrine depositional environments in the Green River Formation, Uinta Basin: expression in outcrop and wireline logs. AAPG Bull. 2014;98(9):1699-715. https://doi. org/10.1306/03201413187.

Cao J, Lei DW, Li YW, et al. Ancient high-quality alkaline lacustrine source rocks discovered in the lower permian Fengcheng Formation, Junggar Basin. Acta Pet Sin. 2015;36(7):781-90. https://doi. org/10.7623/syxb201507002 (in Chinese with English abstract).

Cheng HY. Appraisal parameters of marine carbonatite hydrocarbon source rocks. Mar Geol Front. 2007;23(12):14-8. https://doi. org/10.16028/j.1009-2722.2007.12.007 (in Chinese with English abstract).

Cheng KM, Wang Z, Zhong NN, et al. Theory and practice of hydrocarbon generation of carbonates. Beijing: Petroleum Industry Press; 1996. p. 92-104 (in Chinese).

Cordell RJ. Carbonates as hydrocarbon source rocks. Dev Pet Sci. 1992;30:271-329. https://doi.org/10.1016/S0376-7361(09)70128 -1 .

Daher SB, Nader FH, Strauss H, et al. Depositional environment and source-rock characterisation of organic-matter rich upper Santonian-upper Campanian carbonates, northern Lebanon. J Pet Geol. 2014;37(1):5-24. https://doi.org/10.1111/jpg.12566.

Daly AR, Edman JD. Loss of organic carbon from source rocks during thermal maturation. AAPG Bull. 1987;71(5):546-546.

Degens ET, Chilingar GV, Pierce WD. On the origin of petroleum inside freshwater carbonate concretions of Miocene age. In: Colombo U, Hobson GD, editors. Advances in organic geochemistry. New York: MacMillan; 1964. p. 149-64.

Edman JD, Pitman JK. Geochemistry of Eagle Ford group source rocks and oils from the first shot field area, Texas. In: Gulf Coast Association of Geological Societies 60th Annual Convention. San Antonio: Gulf Coast Association of Geological Societies; 2010. p. 217-234. 
Epstein AG, Epstein JB, Harris LD. Conodont colour alteration-an index to organic metamorphism. Geol Surv Prof Pap. 1977. https ://doi.org/10.1130/0016-7606(1987)99814:TCHOSA2.0.CO;2.

Fang RH, Li MJ, Lu HT, et al. Oil charging history and pathways of the Ordovician carbonate reservoir in the Tuoputai region, Tarim Basin, NW China. Pet Sci. 2017;14(4):662-75. https://doi. org/10.1007/s12182-017-0196-8.

Feng GX, Chen SJ. Relationship between the reflectance of bitumen and vitrinite in rock. Nat Gas Ind. 1988;8(3):20-5 (in Chinese with English abstract).

Fu JM, Jia RF. Main forms of disseminated organic matter in carbonate rocks, their evolutionary characteristics and significance in oil-gas evaluation. Geochimica. 1984;1:1-9 (in Chinese with English abstract).

Fu JM, Jia RF, Liu DH, et al. Organic geochemistry of carbonate sediments: applications in origin and evaluation of oil, gas, coal and strata-bound resources. Beijing: Science Press; 1989. p. 1-205 (in Chinese).

Geatches DL, Clark SJ, Greenwell HC. Role of clay minerals in oilforming reactions. J Phys Chem A. 2010;114(10):3569-75. https ://doi.org/10.1021/jp9096869.

Gehman HMJ. Organic matter in limestones. Geochi Cosmochim Acta. 1962;26(8):885-97. https://doi.org/10.1016/0016-7037(62)90118 $-7$.

Hakami A, Ellis L, Al-Ramadan K, et al. Mud gas isotope logging application for sweet spot identification in an unconventional shale gas play: a case study from Jurassic carbonate source rocks in Jafurah Basin, Saudi Arabia. Mar Pet Geol. 2016;76:133-47. https ://doi.org/10.1016/j.marpetgeo.2016.05.003.

Ham WE, Pray LC. Modern concepts and classifications of carbonate rocks. In: Ham WE, editor. Classification of carbonate rocksa symposium. Am. Assoc. Petrol. Geologists, Memoir; 1962. p. 2-19.

Harris NB, Freeman KH, Pancost RD, et al. The character and origin of lacustrine source rocks in the lower Cretaceous synrift section, Congo Basin, west Africa. AAPG Bull. 2004;88(8):1163-84. https://doi.org/10.1306/02260403069.

Huang JZ, Lv ZG. How to judge carbonate rock as source rock: a case of Sichuan Basin. Mar Orig Pet Geol. 2011;16(3):8-14. https:// doi.org/10.3969/j.issn.1672-9854.2011.03.002 (in Chinese with English abstract).

Hughes WB. Use of thiophenic organosulfur compounds in characterizing crude oils derived from carbonate versus siliciclastic sources. In: Palacas JG, editor. Petroleum geochemistry and source rock potential of carbonate rocks., Geologists, studies in geologyNew York: American Association of Petroleum; 1984. p. 181-96.

Hunt JM, McNichol AP. The cretaceous Austin Chalk of South Texas-a petroleum source rock. In: Palacas JG, editor. Petroleum geochemistry and source rock potential of carbonate rocks., Geologists, studies in geologyNew York: American Association of Petroleum; 1984. p. 117-25.

Hunt JM. The origin of petroleum in carbonate rocks. In: Chilingar GV, Bissell HJ, Fairbridge RW, editors. Carbonate rocks, vol. 9. New York: Elsevier; 1967. p. 225-51.

Huo ZG, Jiang T, Pang XQ, et al. Evaluation of deep carbonate source rocks with low TOC and contribution to oil-gas accumulation in Tazhong area, Tarim Basin. Earth Sci. 2016;41(12):2061-74. https://doi.org/10.3799/dqkx.2016.143 (in Chinese with English abstract).

Jarvie DM. Components and processes affecting producibility and commerciality of shale resource systems. Geol Acta. 2014;12(4):30725. https://doi.org/10.1344/geologicaacta2014.12.4.3.

Jia ZZ, Lin CY, Ren LH, et al. Selective dissolution of eodiagenesis cements and its impact on the quality evolution of reservoirs in the Xing'anling Group, Suderte Oil Field, Hailar Basin, China.
Pet Sci. 2016;13(3):402-17. https://doi.org/10.1007/s1218 2-016-0110-9.

Jones RW. Comparison of carbonate and shale source rocks. AAPG Bull. 1984;68(4):163-80. https://doi.org/10.1306/AD460EA416F7-11D7-8645000102C1865D.

Katz B, Lin F. Lacustrine basin unconventional resource plays: key differences. Mar Pet Geol. 2014;56:255-65. https://doi. org/10.1016/j.marpetgeo.2014.02.013.

Katz BJ, Dittmar EI, Ehret GE. A geochemical review of carbonate source rocks in Italy. J Pet Geol. 2000;23(4):399-424. https://doi. org/10.1111/j.1747-5457.2000.tb00494.x.

Kirkland DW, Evans R. Source-rock potential of evaporitic environment. AAPG Bull. 1981;65(2):733-733. https://doi. org/10.1306/2F918EF5-16CE-11D7-8645000102C1865D.

Larskaia ES. Disseminated organic matter of carbonate rocks and the oil forming process. Izv Akad Nauk SSSR Ser Geogr. 1977;12:90-8.

Leighton MW, Pendexter C. Carbonate rock types. AAPG Bull. 1962;1:33-61.

Li DC. Basic geological characteristics of marine facies strata and fields in China compared with in the globe. Mar Orig Pet Geol. 2005;10(1):13-7. https://doi.org/10.3969/j.issn.16729854.2005.01.003 (in Chinese with English abstract).

Liu GD, Chen ZL, Wang XL, et al. Migration and accumulation of crude oils from Permian lacustrine source rocks to Triassic reservoirs in the Mahu depression of Junggar Basin, NW China: constraints from pyrrolic nitrogen compounds and fluid inclusion analysis. Org Geochem. 2016;101:82-98. https://doi. org/10.1016/j.orggeochem.2016.08.013.

Liu WH, Borjigin T, Wang XF, et al. New knowledge of hydrocarbon generating theory of organic matter in Chinese marine carbonates. Pet Explor Dev. 2017;44(1):159-69. https://doi.org/10.1016/ S1876-3804(17)30020-4.

Lü ZX, Zhang SL, Yin C, et al. Features and genesis of Paleogene high-quality reservoirs in lacustrine mixed siliciclastic-carbonate sediments, central Bohai Sea, China. Pet Sci. 2017;14(1):50-60. https://doi.org/10.1007/s12182-016-0147-9.

Ma SP, Luo CS, Tian CT, et al. Hydrocarbon-generating characteristics of lacustrine carbonate rocks. J Chengdu Univ Technol. 2012a;39(6):583-6 (in Chinese with English abstract).

Ma ZL, Zheng LJ, Li ZM. The Thermocompression simulation experiment of source rock hydrocarbon generation and expulsion in formation porosity. Acta Sedimentol Sin. 2012b;30(5):955-63 in Chinese with English abstract.

Moldowan JM, Seifert WK, Gallegos EJ. Relationship between petroleum composition and depositional environment of petroleum source rocks. AAPG Bull. 1985;69(8):1255-68. https://doi. org/10.1080/10916469808949779.

Oehler JH. Carbonate source rocks in The Jurassic Smackover trend of Mississippi, Alabama, and Florida. In: Palacas JG, editor. Petroleum geochemistry and source rock potential of carbonate rocks., Geologists, studies in geologyNew York: American Association of Petroleum; 1984. p. 63-9.

Palacas JG, Anders DE, King JD. South Florida Basin-a prime example of carbonate source rocks of petroleum. AAPG Bull. 1984;30:71-96. https://doi.org/10.1306/St18443.

Palacas JG. Carbonate rocks as sources of petroleum: geological and geochemical characteristics and oil-source correlations. World Pet Congr. 1983;2:31-43.

Peng L, Cantrell D. Reactive transport modelling of reflux dolomitization in the Arab-D reservoir, Ghawar field, Saudi Arabia. Sedimentology. 2016;63(4):865-92. https://doi.org/10.1111/sed.12241

Peters KE, Cassa MR. Applied source rock geochemistry. In: Magoon LB, Dow WG, editors. The petroleum system from source to trap. AAPG Memoir 60. AAPG Tulsa; 1994. p. 99-117. 
Pratt LM. A paleo-oceanographic interpretation of the sedimentary structures, clay minerals, and organic matter in a core of the Middle Cretaceous Greenhorn Formation drilled near Pueblo, Colorado. Princeton, New Jersey, Princeton University unpublished Ph.D. dissertation; 1982.

Qi Y, Zhu YH, Yin L, et al. The correlation between conodont color alteration index (CAI) and vitrinite reflectance. Acta Micropalaeontol Sin. 1998;15(2):220-4. https://doi.org/10.1088/0256307X/15/12/010 (in Chinese with English abstract).

Qin JZ, Liu BQ, Guo JY, et al. Discussion on the evaluation standards of carbonate source rocks. Pet Geol Exp. 2004;26(3):281-6. https ://doi.org/10.3969/j.issn.1001-6112.2004.03.012 in Chinese with English abstract.

Ren JL, Jin J, Ma WY, et al. Analysis of hydrocarbon potential of Fengcheng saline lacustrine source rock of Lower Permian in Mahu Sag, Junggar Basin. Geol Rev. 2017;63(B04):51-2. https ://doi.org/10.16509/j.georeview.2017.s1.026 (in Chinese).

Rogers MA. Application of organic facies concepts to hydrocarbon source rock evaluation. In: Proceedings of the 10th world petroleum congress. 1979;2:23-30.

Shang XD, Moczydłowska M, Liu P, et al. Organic composition and diagenetic mineralization of microfossils in the Ediacaran Doushantuo chert nodule by Raman and petrographic analyses. Precambrian Res. 2018;314:145-59. https://doi.org/10.1016/j. precamres.2018.05.029.

Stank CV, Esteves FR, Martins CC, et al. The Linguado, Carapeba, Vermelho, and Marimba giant oil fields, Campos basin, offshore Brazil. AAPG Bull. 1992;74:9.

Su AG, Chen ZY, Liang XL, et al. Oil and Gas Formation in the Qinghai-Tibet Plateau: the Cenozoic in the Western Qaidam Basin. Beijing: Geol. Publishing House; 2006 (in Chinese).

Tian CT, Ma SP, Yang Y, et al. Comparison of hydrocarbon generation conditions between lacustrine and marine carbonate source rocks. Oil Gas Geol. 2014;35(3):336-41. https://doi.org/10.11743/ogg20 1406 (in Chinese with English abstract).

Tissot B, Welte DH. Petroleum formation and occurrence. 2nd ed. Berlin: Springer; 1984.

Tissot B, Deroo G, Hood A. Geochemical study of the Uinta Basin: formation of petroleum from the Green River Formation. Geochim Cosmochim Acta. 1978;42(10):1469-85. https://doi. org/10.1016/0016-7037(78)90018-2.

Tuo JC, Zeng FG, Huang XZ, et al. Biyang depression - an example of lacustrine carbonate as source rocks of petroleum. Acta Sedimentol Sin. 1997;15(A12):64-9 (in Chinese with English abstract).

Veber VV, Gorskaya AI. Bitumen formation in sediments of carbonate facies. Int Geol Rev. 1965;7(5):816-25.

Wang CY. The conodonts in the lower Yangtze region: indicators of biostratigraphy and organic metamorphic maturity. Beijing: Science Press; 1993. p. 126-33 (in Chinese).

Wang FY, He P, Hao SS, et al. Organic petrological characteristics and organic constituents classification of carbonate source rocks. J Univ Pet China. 1995;19(3):7-11 (in Chinese with English abstract).

Wang GL, Wang TG, Simoneit BRT, et al. Sulfur rich petroleum derived from lacustrine carbonate source rocks in Bohai Bay
Basin, East China. Org Geochem. 2010;41(4):340-54. https:// doi.org/10.1016/j.orggeochem.2009.12.010.

Wang L, Jin Q, Lin LM, et al. Characteristics of quality Tertiary source rocks in the West Qaidam Basin. Nat Gas Ind. 2009;29(2):23-6. https://doi.org/10.3787/j.issn.1000-0976.2009.02.005 (in Chinese with English abstract).

Wang ZC, Zhao WZ, Hu SY, et al. Reservoir types and distribution characteristics of large marine carbonate oil and gas fields in China. Oil Gas Geol. 2013;34(2):153-60. https://doi.org/10.11743 /o9920130202 (in Chinese with English abstract).

Wang ZY, Cheng KM. Hydrocarbon generation mechanism and "Three-stage" hydrocarbon generation model of carbonates. Sci China Ser D. 1997;27(3):250-4 (in Chinese).

Xie YX, Zhou W, Guo M, et al. Typical cases analysis of effective source rocks existence in ancient carbonate rock in the middle basins of China. Lithol Reserv. 2016;28(6):16-21. https://doi. org/10.3969/j.issn.1673-8926.2016.06.003 (in Chinese with English abstract).

Yang H, Bao HP, Ma ZR. Reservoir-forming by lateral supply of hydrocarbon: a new understanding of the formation of Ordovician gas reservoirs under gypsolyte in the Ordos Basin. Nat Gas Ind. 2014;34(4):19-26. https://doi.org/10.3787/j.issn.10000976.2014.04.003 (in Chinese with English abstract).

Yang H, Zhang WZ, Zan CL, et al. Geochemical characteristics of Ordovician subsalt gas reservoir and their significance for reunderstanding the gas source of Jingbian gasfield, east Ordos Basin. Nat Gas Geosci. 2009;20(1):8-14 (in Chinese with English abstract)

Yurchenko IA, Moldowan JM, Peters KE, et al. The role of calcareous and shaly source rocks in the composition of petroleum expelled from the Triassic Shublik Formation, Alaska North Slope. Org Geochem. 2018;122:52-67. https://doi.org/10.1016/j.orggeochem .2018.04.010.

Zhang SC, Liang DG, Zhang DJ. Evaluation criteria for Paleozoic effective hydrocarbon source rocks. Pet Explor Dev. 2002;29(2):8-12. https://doi.org/10.3321/j.issn:1000-0747.2002.02.002 (in Chinese with English abstract).

Zhang Y, Gable CW, Zyvoloski GA, et al. Hydrogeochemistry and gas compositions of the Uinta Basin: a regional-scale overview. AAPG Bull. 2009;93(8):1087-118. https://doi.org/10.1306/05140 909004.

Zhao L, Wang SQ, Zhao WQ, et al. Combination and distribution of reservoir space in complex carbonate rocks. Pet Sci. 2016;13(3):450-62. https://doi.org/10.1007/s12182-016-0117-2.

Zhao W, Wang ZY, He Q, et al. Gas-generated mechanism of marine carbonate source rocks in China. Sci China Ser D. 2005;35(7):638-48. https://doi.org/10.3321/j.issn:10069267.2005.07.005 (in Chinese).

Zumberge JE. Source rocks of the La Luna Formation (Upper Cretaceous) in the Middle Magdalena Valley, Colombia. In: Palacas JG, editor. Petroleum geochemistry and source rock potential of carbonate rocks., Geologists, studies in geologyNew York: American Association of Petroleum; 1984. p. 127-33. https:// doi.org/10.1016/0146-6380(90)90053-3. 